\title{
Local Revenue Mobilization and Composite Budget Implementation in Ghana: Examining the Challenges
}

\author{
Benjamin Otchere-Ankrah, $\mathrm{PhD*}$ \\ Department of Management and Public Administration, \\ Central University, Accra, Ghana \\ Miotso near Dawhenya. \\ Off the Accra - Aflao Road
}

Received: Sep. 25, $2021 \quad$ Accepted: Nov. 8, $2021 \quad$ Online published: Nov. 22, 2021

doi:10.5296/jpag.v11i4.19242ＵRL: https://doi.org/10.5296/jpag.v11i4.19242

\begin{abstract}
Central governments recognize the key role played by local governments in the developmental agenda of these local areas, especially the effort at generating sufficient revenue locally to fund its own projects and programs. Ensuring effectiveness in decentralization calls for sufficient financial resources to help run the administrative machinery and foster local-level development. The study set out to examine the main challenges affecting local revenue mobilization in Ghana using the experience of three selected districts. To understand these key challenges, this study adopted the case study design to select three administrative assemblies in Ghana. The study found many delays in releasing funds from the central government in terms of releases, poor IGF mobilization affecting operationalization of the district budgets, and ability to carry out socio-economic and infrastructural projects. The study recommends that a PPP arrangement for revenue mobilization should be structured to benefit the Assembly.
\end{abstract}

Keywords: challenges, composite budget, Ghana, mobilization, revenue

\section{Introduction}

Decentralisation has been pursued in most developing countries to foster political, social, and economic transformation and the overall development of localities. Akudugu (2012) contends that "decentralisation has been pursued to bring governance and development decision-making process closer to the ordinary citizen at the sub-national level" (p. 22). In Africa, and many parts of the developing world, the World Bank and the International Monetary Fund, in particular, have played an instrumental role in promoting the decentralisation agenda as a means of overcoming the inefficiencies associated with the 
centralised system of governance (Bardhan, 2002). Ensuring effectiveness in decentralization calls for sufficient financial resources to help run the administrative machinery and foster local development. Fiscal decentralization, in this context, composite budget system (CBS), transfers responsibilities, power, and resources to the lower-level public authority to mobilize funds for development that is semi-autonomous and independent from the devolving authority when narrowed down to devolution. Local authorities are given responsibilities and financial means within the national level to determine the scope and quality of services and the number of funds needed to deliver these services. Kessey (2002) calls for a vigorous revenue mobilization drive if the metropolitan, municipal, and district assemblies (MMDAs) perform better. They mention that the effectiveness of revenue mobilization depends on fiscal policy, revenue administration, monitoring operations, and performance assessments. Unfortunately, many MMDAs do not generate enough revenue. Their inability to mobilize enough revenue is numerous, hence affecting the implementation of public policies such as the composite budget system in Ghana. For example, Kessey (2002) list corrupt practices, poor mobilization strategies, poor budget control, and poor financial management as the primary reasons. The Local Government Act, Act 936 of 2016 mandates the Metropolitan, Municipal, and District Assemblies (MMDAs) to collect such revenues as levies, basic rates, property rates, market tolls, etc., as sources of revenue for their developments. All things being equal, these sources of revenue can be maximized under a reasonably good economic environment. Completing the composite budgeting ensures coordination in the revenue and expenditure of decentralized departments and MMDAs in a respective local government area. Ensuring its effective operationalization calls for an adequate and reliable flow of resources. Indeed, the capacity of local governments to effectively discharge their developmental role or deliver services to the residents is primarily determined by the stock of financial resources available to them. However, many MMDAs, in most cases, are not able to raise the required internally generated funds from their people to actualize their expenditure patterns and tend to rely on the central government for the District Assembly Common Fund. Meanwhile, the DACF is not reliable for any meaningful planning because of late disbursement and its challenges, including deduction at source.

Therefore, decentralized local governments have not performed very well in the promotion of economic development and poverty reduction (Romeo \& Spyckerelle, 2003; Crawford, 2008; Chinsinga, 2008). This has primarily been blamed on the inability of central governments to promote fiscal decentralisation that will ensure the transfer of financial resources to local governments (Steiner, 2010; Chinsinga, 2008) and, most essential constraints in IGF mobilization. Smoke (2003) contends that political and institutional decentralisation would have little impact without properly defined fiscal decentralization. Poorly articulated roles and resource deficiencies can cripple local governments and undermine incentives for local officials and elected representatives to perform effectively. The situation is compounded by the inability of many local government authorities to effectively mobilise revenues from their sources to finance local development initiatives.

Meanwhile, Section 34 of the Local Government Act 462 of 1993 empowers the District Assembly to charge fees and generate other forms of revenues for both its recurrent 
expenditure and physical development programs. Aside from fees, licenses, and other charges for services rendered by the Assembly, property owners and businesses also pay annual rates and fees to the Assembly. Other forms of internally generated revenue to the District Assembly are royalties that come from Stool Lands and development permits within the geographical and administrative area of the District. Section 10 of Act 462 of 1993 is very explicit about the functions of the District Assembly. According to Diaw (1996), adequate financial resources that are independent of central government are essential for the efficient operation of local governments, especially in the implementation of their plans and expenditure patterns.

But effective revenue mobilisation at the district level appears elusive. The low level of internally generated funds of Local governments makes them overly dependent on external sources to finance most of their expenditure items. This high degree of dependence could affect the autonomy of MMDAs and undermine their decision-making power or authority. It has been observed by Dickovick (2005) that the lack of own-source revenues contributes to dependence on the center, especially for capital investment. The point has been reiterated by Bailey (1999) that local autonomy would be severely limited if the central government could control all the sources of revenue for each local government, thereby controlling the spending of individual authorities. This suggests that MMDAs need to put in adequate mechanisms to raise the capacities of their revenue management teams to raise the required financial resources to carry out the development required by the people.

This paper examines the challenge of local revenue mobilization and mechanisms for enhancing adequate IGF pool for local governments in Ghana to optimize the effective implementation of the composite budgeting system since internal revenue items remain paramount. The paper is organized into five main sections; beyond this introduction, section two entails a brief conceptual overview and framework; section three presents study methodology, procedures, and data sources; section four analyses and discusses data, while section five presents conclusions and recommendations.

\section{Literature Review}

\subsection{Fiscal Decentralization}

Fiscal decentralization is the transfer of responsibilities, power and resources to a level of public authority that is autonomous and fully independent from the devolving authority when contracted down to devolution (Dick-Sagoe, 2012). The Local authorities are given responsibilities and financial means within the national levels determining the amount of funds needed to deliver these services and the possibility and quality of services to be provided to the local people.Fiscal decentralization could also include deconcentration and delegation. Deconcentration is the transfer of responsibilities, power and resources from the ministries and agencies to the local representatives, for developmental projects (Dick-Sagoe, 2012). The officers at the local level cannot act discretionally or raise their own revenues unless ordered by the central body. An element of fiscal decentralization is that, the local governments are given roles and discretionary powers on how to achieve successful delivery of services in the communities. Financial decentralization system envisages the establishment 
of financial procedures and practices, which will ensure a steady and adequate disbursement of funds at the appropriate times to the districts to meet the ever-increasing expenditures and also seeks to put in place a process whereby financial decision can be taken and implemented without hindrance from the centre.

\subsection{Rationale for Fiscal Decentralization}

Fiscal decentralization that seeks to empower local governments and people to adequately take charge of planning and budgeting has been discussed in the literature. According to Heeks (1999), this perspective became much pronounced in the age of public sector reforms which saw decentralization as a more acceptable and the innovative approach to governance in both developed and the developing world. There have been varying schools of thought with regards to the main drivers of fiscal decentralization. The idea of decentralizing public finance and service delivery - holding inter jurisdictional spillovers constant — provides three key advantages (1) promotes efficiency of resource allocation, (2) enhances accountability with regards to how officials dispense resources as well as tendency to cut corruption within local governments (3) promotes cost recovery. The three key dimensions of local governance improvement which comes with fiscal decentralization and closely interwoven and would largely be effective if the local government is more democratic and open to the public as in the case of Ghana.

Scholars argue that a major popular theoretical argument supporting fiscal decentralization is its tendency to lead to efficiency in resource allocation at the local level. A primary objective or mandate of decentralized offices and administrations of government is the provision of goods and services to enhance the well-being of population limited to their own jurisdictions. Therefore, by providing such agency or unit with adequate power, they are able to channel outputs of such goods and services to the precise preferences and contexts of their geographical area. In other words, decentralized goods and service provision leads to an improvement in economic welfare at least more than the more uniform levels of such services that comes under centralized or national provision (Oates, 2005). Another important factor that promotes allocative efficiency is the fact local government appear more responsive to local people and conditions than the central government (Tiebout 1956). According to Tiebout (1956) the process of fiscal decentralization enables governments to allocate their resources effectively in context-specific activities which are responsive to local people's needs thereby spurring up some form of competition among local governments. For instance, assuming government rolls out the one-district one-factory policy and local governments become the main drivers of this policy, it is possible that two or three districts will at least be engaged in a district that provides same or similar products.

Fiscal decentralization has been theorized to come with accountable and transparent systems with regards to how financial resources are disbursed and utilized in local governments. According to Gurgur and Shah (2005), a major strength of decentralized or participatory budgeting system is that it helps to promote empowerment and accountability largely because the process takes into consideration the contextual socio-political and economic environment. According to Ostrom et al (1993), decentralizing comes with greater checks and 
accountability which helps in reducing corruption and wastages although requires contextual measures (Gurgur \& Shah, 2005; Fisman \& Gatti, 2002). Moreover, as local groups and actors become more interested in demanding accountability, decentralization has potential to reduce misuse and misappropriation of public resources. Corruption and wastages occur in government when few public privileged public officials collude to defraud the state; consequently, by devolving powers and resources to local areas, activities become.

The idea of fiscal decentralization injecting competition among local governments has an added advantage of making local officials pursue customer-driven investments which are more likely to meet expectations of local people and patronage of services. When local service delivery meet local people expectations, they tend to pay for services and even honor their tax obligations without much coercion because they even appear more willing to do so (Sepúlveda \& Martínez-Vázquez, 2010). The literature provides an appreciable relationship between decentralization and poverty reduction which suggests that by properly embarking on decentralization it would have a trickle-down effect on local people especially the disadvantaged. This is because local government officials through their activities could significantly facilitate, promote or coordinate effective implementation of social policies that target the less privileged in society.

\subsection{Challenges Associated with Fiscal Decentralization}

The processes and procedures involved in fiscal decentralization and composite budgeting are normally affected by power dimensions as it involves interplay between diverse stakeholders, agencies and citizenry in general. According to Norton and Elson (2002) the budgeting process at times may lead to exclusion of other groups; such may be a clear demonstration of uneven power relations in the budgeting process. Scholars such as Wampler (2000) explain that people and groups participation in local government activities and processes is usually guided by their perception of improvement and access to quality services. The author suggests that if people perceive local governments as performing satisfactorily, they are more likely to participate in the local government processes, and in this context participate in the budgeting process.

Another challenge that has become associated with fiscal decentralization is that local governments may compete with central government for tax revenues. Scholars (Oates, 2005) argue that some forms of fiscal decentralization could lead to a loss of potential economies of scale which may cause a rise in administration cost and government size. The point is that an overhead cost if borne by national government could have helped at least two or three local governments to benefit so that the aggregate cost would reduce. However, increased decentralization may lead to different local governments engaging in a similar capital expenditure where just one could have resulted in effective sharing and efficiency in expenditure. To address this challenge, there is a need for local governments to liaise among themselves and collaborate in project designs and executions. This will help in pooling resources together especially in the design of huge sunk cost and to avoid the free-rider syndrome.

Technical nature of budgeting and capacity constraints of local officials in local governments 
in most cases also serve as barriers to proper fiscal decentralization and composite budgeting process. According to Prud'homme (1995) most decentralized agencies and entities do not have quality local bureaucrats with the requisite knowledge, skills and experiences which mostly may weaken public budgeting processes and expenditure pattern due to a tendency for higher supply costs of public services.

\section{Method}

The case study design within the qualitative approach was employed for the study. According to Simons (2009), a case study is an in-depth exploration from multiple perspectives of the complexity and uniqueness of a particular policy or program in a 'real-life context. Case study is considered appropriate when there is limited information or investigation about the phenomenon (Creswell, 2003). Simons (2009) defined a case study as an in-depth exploration of the complexity and uniqueness of a particular project, policy, institution and program in a 'real life' context using multiple perspectives. Hence, an equal attention was given to the selected assemblies to ascertain whether or not the guidelines that were provided for the implementation are being followed and their inherent benefits. The cases were time and activity bound, and this study therefore gathered detailed information using a wide range of data collection tools and techniques over a sustained period of time. To understand the key challenges facing local revenue mobilization, this study adopted the multiple case study design to select three administrative assemblies: Shai Osudoku, Dangme East, and Akuapim North. The main tools for primary data collection involve interviews, focus group discussions, and observations.

The purposive sampling method was used in selecting the respondents. The main goal for using the purposive sampling technique is towards fulfilling the objective of this study through focusing on identifying characteristics of the target population under study, which have important bearing on the research questions. The administrators and officials were chosen for the interview because they have first-hand information, experience, and requisite knowledge on the subject matter. The officials who comprised the sampling frame were selected because they have informed knowledge and copious working experience on the research questions. Again, the respondents are deeply involved in preparing, implementing, and monitoring the composite budget at the various assemblies. A total of forty-two (42) participants comprising public officials at the selected assemblies, officials at the Ministry of Local Government (MLG), Ministry of Finance (MoF), and District Assembly Common Fund (DACF), and other key stakeholders, including assembly members and residents were engaged in gathering relevant data from them. 


\section{Ml Macrothink}

Table 1. Research Participants

\begin{tabular}{|l|l|l|l|l|l|l|l|l|l|l|}
\hline PARTICIPANT & OS & \multicolumn{2}{l|}{ DE } & \multicolumn{2}{l|}{ AN } & DACF & MLG & MoF & TOTAL \\
\hline & INT & FGD & INT & FGD & INT & FGD & INT & INT & INT & \\
\hline Bureaucrats & 3 & $5(2)$ & 3 & $5(2)$ & 3 & $5(2)$ & $\mathbf{3}$ & $\mathbf{2}$ & $\mathbf{3}$ & $\mathbf{3 8}$ \\
\hline Department & 3 & --- & 3 & --- & 4 & --- & --- & --- & --- & $\mathbf{1 0}$ \\
\hline $\begin{array}{l}\text { Assembly } \\
\text { Members }\end{array}$ & 5 & --- & 3 & --- & 5 & --- & --- & -- & --- & $\mathbf{1 3}$ \\
\hline Beneficiaries & 3 & $5(1)$ & 3 & $5(1)$ & 3 & $5(1)$ & --- & --- & --- & $\mathbf{2 7}$ \\
\hline TOTAL & $\mathbf{1 4}$ & $\mathbf{1 3}$ & $\mathbf{1 2}$ & $\mathbf{1 3}$ & $\mathbf{1 5}$ & $\mathbf{1 3}$ & $\mathbf{3}$ & $\mathbf{2}$ & $\mathbf{3}$ & $\mathbf{8 8}$ \\
\hline
\end{tabular}

Source: Field Data, 2017

Note: $\mathrm{INT}=$ Interviews

$\mathrm{FGD}=$

Focus

Group

Data from the field was then organized for analysis and interviews transcribed and handwritten notes typed serving as a backup in the event that the recording equipment failed. Recorded audio data were transcribed verbatim into English. Verbatim transcription eliminates the tendency of losing respondent's contribution to interpretation or summary during transcribing. The next stage involved the categorization of the data into various themes to facilitate easy processing. A conclusion can then be made on the data gathered in the study concerning implementing the composite budget system in the study areas.

\section{Results/Findings}

The study set out to examine the main challenges affecting local revenue mobilization in Ghana using the experience of three selected districts. Through a thorough review of the Local Government Act, the study enumerated both internal and external sources of revenue available to MMDAs. These are highlighted in table 2 below:

Table 2. Sources of funds for MMDAs in Ghana

\begin{tabular}{|l|l|}
\hline EXTERNAL SOURCE & INTERNAL SOURCE \\
\hline District Assembly Common Fund & Internally Generated Fund \\
\hline Central Government Transfers & Property rates \\
\hline District Development Fund & Levies \\
\hline Donors & Tolls and Rates \\
\hline Other Government Transfers & Fines and Licence \\
\hline
\end{tabular}

Source: Developed out of Act 936

\section{Revenue generation challenges}

Local governments are expected to mobilize revenues from various economic activities within their jurisdictions. From the cases analyzed, local governments do not rise to the occasion for local revenue mobilization. An officer intimated

"our primary sources are Taxes, royalties, fines, tolls, Business Operating rate, property rate. But here, sometimes we send them their bills, but they do not honor it ...The challenge is that the funds are not forthcoming, and we are using what we have to pay revenue collectors so that the government will absorb them. 
Socio-economic context

This was supported by an officer at the Akuapim North District whose response suggests that most local governments face local mobilization problems.

"It is because of the activities, every District is endowed with some activities like the property rate here you see that people are poor, the economic activity is poor, and you go to some places, and people are not willing to pay you sometimes you will see that even the person doesn't have money and you go to market the person will tell you to go and come. 50 p so why do you come to the market".

In discussion with a critical respondent at the Akuapim North municipal assembly, he explained:

"In some places, a lot depends on the location of the Assembly. When I was at Fantiakwa in 1988. We had a big market there, the market at Hiamankyini on Tuesdays and Saturdays. We had other markets, and it was helping. That was the primary source of our IGF.

Some of them have market days throughout, from Mondays to Saturdays, like Yilo Krobo, they come to Nkrakan, Wednesday at Somanya, and Thursday they come back to Nkrakan, Friday they are at Somanya. But for us, we have Tuesdays and Fridays, and we have Asema, a tiny place, which is Wednesdays and Saturdays. The properties you have, the hotels, filling stations in your District or municipality all account for how much you can generate as IGF and the people willing to pay, for example, the market toll, lorry park, tickets, and all those things....

The findings above on local revenue mobilization constraints and challenges shrouded with central government transfers worsen the financial health of local governments in Ghana. In other words, executing the composite budget is constrained by political economy factors and the capacity to raise and accumulate enough funds taxes (Skidmore, 1999). However, the literature raises concerns about the relevance of adequate local financial resources to local governments (Diaw, 1996). The narrative above corroborates an argument by Mogues et al. (2009) that the "socio-economic context of local and demographic factors in the jurisdiction of the local government are additional potential determinants of locally generated revenues, especially factors that determine the tax revenue base and the capacity of the local government to collect taxes" (p. 4).

\section{Poor structures and systems}

Meanwhile, some respondents blamed the poor IGF mobilization on the systems and structures in place. Lamenting on the general problem of poor IGF in the country, an officer at MLG remarked:

I see it more as a national challenge, is a kind of efficient revenue mobilisation system. You see, in advanced countries or other jurisdictions, the human interface is being reduced, ... we should begin to embark on that process that kind of take away the human face, the interface so that we allow, if we can have a system in place so that the 
system is instead of taking the revenue, either engaging a private person or doing electronic invoicing so that people can just walk to the bank and pay a mixture of all these, it should not be like we have with ECG people carrying bills going to give in the market women, property owners as long as we are going to do this

\section{Collusion and corruption}

Another challenge causing shortfalls in district assembly local revenue mobilization is either inadequate knowledge or collusion between revenue collectors and taxpayers and at times between management and private actors, which reflects in terms of the contract establishing the outsourcing process. A key informant at the Ministry of Finance intimated:

Some of them are engaged in the contracts they didn't have the knowledge of managing the outsourcing the templates were also not there, so they were going the dark and doing all kinds of things... at times, there were no exit clauses, no performance clauses and at times the money is collected and put in that company's account. After some time, they write a cheque for the Assembly.

This was given support by another participant in the same office who brought the argument clearer home.

And some of them too may say, before the private firms came we were collecting 2 million, the firm comes and add 300,000, but the 30\% commission is calculated on the 2.3, so it's like the firm couldn't add.

\section{Over-reliance on central government transfers}

The point above remained paramount in the data gathering process as respondents corroborated the argument that MMDAs over-reliance on central government transfers (DACF). A significant challenge that has made MMDAs not challenged to maximize local revenue mobilization is their over-reliance on central government transfers disbursed periodically. An interviewee at the Local Government Service pointed out:

the assemblies because of the common fund (DACF), they tend to rely more on the common fund and also tend to rely more on DDF or UDG or transfer let me put it like that, they rely more on transfers than they are generating more money from the assemblies because of that some of the revenue sources or IGF sources need to be developed.

Noting the poor systems and apparent lack of zeal in recouping IGF, a key informant at the MoF, in his dissatisfaction with the situation, fumed:

....So sometimes, when they talk about the common fund, I get annoyed. I don't want to hear people complaining about the common fund. The one in your house you are not ready to collect but somebody should go and collect and come and give it to you, and it will be brought to you.

Unfortunately, most of them do not come. We call drivers, hairdressers, many people. In situations, they do not come, we decide for them. If you do not pay, we take you to court. 
Sometimes we employ a task force to ensure they pay/ when you refuse; we take you to court with a penalty. For now, we are having issues with private schools; they are coming individually to complain. But when we call them, they'd not come"

The argument is that every MMDA has many possible and plausible pools of revenue sources to tap into, even at the local level. Each MMDA needs to scan through its environment or context and know how best to raise local revenues either in cash or kind; the latter could be transformed into cash later. An official at the Finance Ministry made this submission:

There are about 86 sources of local revenues available in Act 462. If you don't develop it, you can't generate money from them, ... but once they get common fund they go back to sleep waiting for somebody to bring the money, and that is what some of us have been fighting them that somebody in GRA is walking through the sun to go and collect something for you. Still, you, yourself, the one just lying by your door you are not ready to go and collect it. Don't blame anybody if the common fund is not coming

True to the words above, DACF has proven not to be a reliable source of funding MMDA budgets or projects, at least in a real-time sense which causes challenges in budget implementation at the local level. A finance officer explained:

At first, it was quarterly, and later it was monthly, and now it is ceased but not totally. That was two months ago. It is not regular. With the schools, they don't get it. Some of the departments exist in name but have nothing to run on. We need resources to run. I have even heard that when the circuit officers go to the schools, the school teachers contribute and pay the officer lorry fare. In this sense, the officer cannot be independent. Some even buy the teachers lunch.

\section{Two compelling canons of local taxation}

It also emerged from the study that IGF has become problematic for the assemblies because compliance levels remain very minimal. They explained that people or prospective taxpayers primarily seek to notice some levels of development in their communities before they comply with honoring their tax obligations. A finance officer pointed a rather long narrative to explain the situation.

"two issues and this one I am expressing a private opinion. When it comes to issues of revenue, 1, is it affordable, 2. Is it beneficial? ... The answer is No, the rates are not too much, but the challenge with IGF in this country is especially about property rate is that, because the rates are low, the Assemblies are not able to put it back to the communities in which they collected them from. So I will give instructions, like this area East Legon, if AMA, step in here to take property rates. They should be able to plow back the same, improving their sanitation, improving their drainage, improving their roads, or any form of municipal services. But the amount is, in many instances, not enough. You could imagine if a specific property in East Legon is paying like GH $\not \subset 100.00$, how many of those would you be able to generate before you can build a $1 \mathrm{~km}$ of the road, so these are the two issues?. 
A revenue superintendent gave this point support in another municipality who put forward:

Assemblies do not generate enough to put back to the community to know that this is what we are benefitting. Because they cannot raise enough, and because they are not able to do it, communities also think there is no benefit in doing this. After all, when we pay, we will not get anything in return, so the government has introduced a policy that at least $20 \%$ of IGF should be used for developmental work. Even with this, you will get different assemblies they cannot implement, so that is the challenge.

Different stakeholders view the problem differently; while the district assemblies appear to point to the structural challenges and difficulties in mobilizing IGF, actors from the central government agencies view such as irresponsibility. The latter could hold as local government actors acknowledge they have not done their best to raise adequate revenues. The over-reliance on central government transfers, which crowd out local government revenue mobilization has been noted by Wildasin (1984), who theoretically observes the impact of different types of intergovernmental transfers (matching grants versus lump-sum grants) on local taxation efforts. In an empirical study using econometrics to assess the phenomenon, Dahlberg et al. (2008) observed that endogeneity of grants neither causes a crowding-in nor a crowding-out effect on local tax revenues. From data gathered from the three local governments, it suggests that MMDAs do not obtain the requisite financial resources necessary for any meaningful implementation of their action plans. An informant summed up the net effect of these challenges highlighted above at MLG:

"Assemblies are allowed to generate their funds; that is what we call the IGF, it is already there, and the assemblies are doing it. However, the share of IGF and the total revenue is woefully inadequate; maybe as stakeholders, we need to find a way to get the assemblies to have the enthusiasm and commitment to enforce their resolutions. I mean, you will move around the country, and you will see that not all property owners pay tax. Even in cases where they pay, the rate or the amount of monies involved is woefully inadequate. These are the sources by which the assemblies can make money, so until the assemblies can generate so much from the internal sources Central government, I don't think how much can be enough for them."

Therefore, without access to adequate financial resources, which emanates from delays in releases, non-release of funds, and poor local revenue mobilization, the idea of composite budgeting as an appreciable local governance financial model loses its vitality and essence.

\section{Addressing the challenge}

In their attempt to foster effectiveness and efficiency in revenue generation and the pool of resources available to MMDAs, most district assemblies have resorted to innovative techniques of increasing their revenues; consequently, they have resorted to public-private partnerships ostensibly to maximize generation. In other words, most of the assemblies have outsourced the revenue collection function to private actors. This concerns the new public management theorists who posit that the canon of effectiveness, efficiency, and economy will be achieved (Hood 1995; Oxborne \& Gaebler, 1995). What remains problematic is that most 
district assemblies appear to have joined this bandwagon without putting in place the necessary measures to guard against possible challenges associated with such contracts and the debacles. Most of the arrangements or contractual provisions made in these PPP tend to favor the private actors, they are no clauses to challenge them to act outside of the box, and there are no meaningful sanctions if they disregard the terms. For instance, Ada District has entered into such PPP. Yet, the terms will not help bring about meaningful change in revenues generated, except part of such money will be used as commission for the private actors engaged, which will continue to exacerbate the financial position of the assemblies. An officer acknowledged:

We have the local revenue collection people in the Assembly and a part which has been outsourced to a private company; so the local revenue collectors for the Assembly take cash, and the outsourced persons take cheque... the commission collectors (private company collectors) go to market.

The paradox here is that the companies (those who paycheque) are mainly willing to pay (concerned with their corporate reputation) and appear relatively easier to deal with. Yet, such is ceded to private revenue collectors to deal with while the hard part (chasing market women, petty traders, and SMEs) remains the responsibility of the local revenue staff.

\section{Development in the area}

A way forward to enhance IGF mobilization is to encourage local-level development for people to see some level of improvement in their lives or environment. Respondents noted some potential sources of revenues are in locations where the Assembly cannot access due to unmotorable roads or poor road network. It is imperative to get these people at least some form of feeder roads to provide the assembly task force with ease of access while motivating the people to pay tax with enthusiasm. By linking up the areas with road networks, the Assembly will update its database on the potential taxpayers for effective planning and budgeting purposes. A key informant explained:

"When people see physical signs of development, they are motivated to pay. So when you go, they will ask you what you do with the funds. If you can build those things, it helps.

\section{Education and sensitization}

MMDAs need to team up with the Information Services Department and other media platforms to encourage people to honor their civic responsibilities. The same opportunity could educate them on the various roles of the MMDAs and how revenues are used for purposes other than perhaps physical development. With these processes, people will come to terms with the need to pay taxes. The town hall meetings need to be reinforced and should encourage more people to participate.

\section{Upfront payment by private partners}

An innovative approach to enhancing local revenue generation is to involve the private sector in IGF mobilization. This needs to be carried forward through a model where the private sector 
could pre-finance the MMDA and later take up the taxes from taxpayers for the year. This, however, requires effective forecasting and assessment of the revenue base, which also requires reliable data. For example, a key informant from the Ministry of Finance put forward:

yes, whether in a lump sum or installment, the thing is that the right is sold to a private person, the value is One Million, the private person, for instance, bring Eight Hundred Thousand, so he agrees we signed I take my Eight Hundred Thousand upfront, or depending on whatever payment schedule but the liability of collection rest with you. If you are not able to collect, I still get my money and move on.

\section{Conclusion}

The study set out to assess the challenge of local government revenue mobilization among MMDAs in Ghana. This was against the backdrop that CBS implementation in Ghana has been problematic partly due to financial hiccups. Framed along with the implementation structure notion, the study adopted the experiences of three selected local governments. The case study within the qualitative approach was adopted. From the study finding and observation, the following conclusions are drawn: first, although there appear to be numerous IGF sources available to local governments, the socio-economic context of MMDAs affects the revenue potentials. Second, poor IGF mobilization coupled with uncertainties with central government transfer affects the operationalisation of the district budgets and the ability to carry out socio-economic and infrastructural projects. The study again concludes that the implementation structure for mobilizing IGF needs adequate restructuring to generate sufficient IGF. An emerging approach for structural improvement is engagement with the private sector in revenue mobilization. However, the terms in the PPP arrangement for revenue mobilization should be structured to benefit the Assembly. MMDAs could assess the revenue potential and take an upfront advance from the private business and individuals within the particular MMDA. This arrangement will enable effectiveness in the planning and budgeting process of MMDAs.

\section{References}

Akudugu, J. A. (2012). Accountability in local government revenue management: who does what? In Information and Knowledge Management, 2(8), 22-32.

Bailey, S. J. (1999). Local government economics: principles and practice. Palgrave Macmillan. https://doi.org/10.1007/978-1-349-27415-4

Bardhan, P. (2002). Decentralization of governance and development. Journal of Economic perspectives, 16(4), 185-205. https://doi.org/10.1257/089533002320951037

Chinsinga, B. (2008). Decentralization and Poverty Reduction in Malawi-A Critical Appraisal. Decentralisation in Africa: a pathway out of poverty and conflict?

Crawford, G. (2008). Decentralization and the limits to poverty reduction: Findings from Ghana. Oxford Development Studies, 36(2), 235-258. https://doi.org/10.1080/13600810701702002 
Creswell, W. J. (2003). Research Design, Qualitative, Quantitative, and Mixed Methods Approaches. London, Sage.

Dahlberg, M., Mörk, E., Rattsø, J., \& Ågren, H. (2008). Using a discontinuous grant rule to identify the effect of grants on local taxes and spending. Journal of Public Economics, 92(12), 2320-2335. https://doi.org/10.1016/j.jpubeco.2007.05.004

Diaw, K. (1996). Fiscal Mobilisation. An Essential Dimension of Decentralised Planning in Ghana. In Tetteh, P. A., Adarkwa K. K, Kokor J.Y, and Mensa-Bonsu I. F (Eds.): Decentralised Development Planning in Ghana. SPRING Research Series. University of Dortmund. Dortmund.

Dick-Sagoe, C. (2012). Survey of literature of fiscal decentralization as a sustainable local development tool in Ghana', Journal of sustainable development in Africa, 14, 228-51.

Dickovick, J. T. (2005). The measure and mismeasure of decentralisation: subnational autonomy in Senegal and South Africa. The Journal of Modern African Studies, 43(2), 183-210. https://doi.org/10.1017/S0022278X05000807

Fisman, R., \& Gatti, R. (2002). Decentralization and corruption: evidence across countries. Journal of Public Economics, 325-345. https://doi.org/10.1016/S0047-2727(00)00158-4

Gurgur, T., \& Shah, A. (2005). Localization and corruption: Panacea or Pandora's Box? (The World Bank). https://doi.org/10.1596/1813-9450-3486

Heeks, R. (1999). Reinventing government in the information age: International practice in IT-enabled public sector reform, Routledge, New York.

Hood, C. (1995). Emerging issues in public administration. Public administration, 73(1), 165-183. https://doi.org/10.1111/j.1467-9299.1995.tb00822.x

Kessey, D. (2002). Local Revenue Mobilisation, a paper presented on human resource development workshop organized for District Budget Analysts in MMDAs at Achiawkrom, Wood Industry Training Centre.

Mogues, T., Benin, S., \& Cudjoe, G. (2009). Do external grants to district governments discourage own-revenue generation? (Vol. 934). Intl Food Policy Res Inst.

Norton, A., \& Elson, D. (2002). 'What's behind the budget', Politics, Rights and Accountability in the Budget Process, ODI, London.

Oates, W. E. (2005). Toward A Second-Generation Theory of Fiscal Federalism. International Tax and Public Finance, 12(4), 349-373. https://doi.org/10.1007/s10797-005-1619-9

Ostrom, E., Schroeder, L, \& Wynne, S. (1993). Institutional Incentives and Sustainable Development. Westview Press: Boulder.

Oxborne, D., \& Gaebler, T. (1995). Reinventing government. Journal of Leisure Research, 27(3), 302. https://doi.org/10.1080/00222216.1995.11949751 


\section{Macrothink}

Journal of Public Administration and Governance ISSN 2161-7104 2021, Vol. 11, No. 4

Prud'Homme, R. (1995). The dangers of decentralization. The world bank research observer, 10, 201-20. https://doi.org/10.1093/wbro/10.2.201

Romeo, L. G., \& Spyckerelle, L. (2003). Decentralization reforms and commune-level services delivery in Cambodia. Unpublished paper.

Sepulveda, C. F., \& Martinez-Vazquez, J. (2011). The consequences of fiscal decentralization on poverty and income equality. Environment and Planning C: Government and Policy, 29(2), 321-343. https://doi.org/10.1068/c1033r

Simons, H. (2009). Case study research in practice. SAGE publications. https://doi.org/10.4135/9781446268322

Skidmore, M. (1999). Tax and expenditure limitations and the fiscal relationships between state and local governments. Public Choice, 99, 77-102. https://doi.org/10.1023/A:1018311425276

Steiner, S. (2010). How important is the capacity of local governments for improvements in welfare? Evidence from decentralised Uganda. The Journal of Development Studies, 46(4), 644-661. https://doi.org/10.1080/00220380903318046

Tiebout, C. M. (1956). A pure theory of local expenditures. Journal of political economy, 64, 416-24. https://doi.org/10.1086/257839

Wampler, B. (2000). Guide to participatory budgeting. Retrieved on 14/05/2020 from www.internationalbudget.org/resources/library/GPB.pdf

Wildasin, D. E. (1984). On public good provision with distortionary taxation. Economic Inquiry, 22, 227-43. https://doi.org/10.1111/j.1465-7295.1984.tb00681.x

\section{Copyright Disclaimer}

Copyright for this article is retained by the author(s), with first publication rights granted to the journal.

This is an open-access article distributed under the terms and conditions of the Creative Commons Attribution license (http://creativecommons.org/licenses/by/4.0/). 